\section{Risk Factors Identification for Burnout Syndrome in Nurses \\ REVIEW}

\section{Abstract}

Objective: Burnout syndrome (BS) is related to a gradual process of exhaustion and demotivation, characterized by physical and psychological symptoms. The worker loses the sense of his relationship to work. It aims to identify the risks factors of BS in nurses.

Method: This is an integrative review of research literature held in electronic library SciELO and in LILACS and BDENF databases. From the articles found, there was a final sample of 13 articles.

Results: The data revealed that the major risk factors for the development of the BS are: excessive workload, poor pay, poor conditions of work and emotional instability.

Conclusion: In view of this, it is concluded that improvement actions should be thought through activities in education, management and administration enhancing the work quality of nurses in their daily lives. Thus, it is suggested the need for preparation of informative booklets that discuss this syndrome and the creation of conversation rounds among professionals to share their experiences and seek solutions to the identified factors

\footnotetext{
Keywords

Burnout Syndrome; Nursing; Professional Diseases.
}

\section{Introduction}

The fast pace of social changes of the last decades has led to changes at work. This situation affects workers and provides a physical and emotional exhaustion, leading to an excessive accumulation of workload and high-stress levels, directly affecting the physiological stability of the individual, emerging cardiovascular disease, psychiatric disorders, and gastrointestinal disorders. The World Health Organiza-
Lucila Corsino de Paiva1, Ana Carla Gomes Canário², Eneluzia Lavynnya Corsino de Paiva China ${ }^{3}$, Bruna Rodrigues Monteiro4, Ana Katherine Gonçalves da Silveira ${ }^{5}$

1 Master's Degree in Nursing from the Federal University of Rio Grande do Norte/PhD student at the Center for Health Sciences.

$2 \mathrm{PhD}$ in Health Sciences from Universidade Federal do Rio Grande do Norte, Natal, RN, Brazil. Permanent Professor, Department of Physical Education, Faculdade Mauricio de Nassau, Recife, PE, Brazil.

3 Specialist in Emergency and Emergency. Permanent Teacher of the Vocational Training Center. Nurse of the Parnamirim/RN Ready Care Unit. Natal/ RN, Brazil

4 Resident Nursing of the Hospital Federal University of Pernambuco, PE, Brazil.

5 Postdoctor in Health Sciences from Universidade Estadual de Campinas, SP. Associate Professor, Department of Obstetrics and Gynecology, Universidade Federal do Rio Grande do Norte, RN, Brazil.

\section{Contact information:}

Lucila Corsino de Paiva.

Address: Praça João Tiburcio, 638, Cidade Alta. CEP 59025-48. Natal, RN, Brazil.

झ lucilacorsinodepaiva@gmail.com 
tion (WHO) indicates that stress is in daily life, with a negative impact on quality of life [1].

In this way, by their needs, some types of work require more attention and emotional distress, directly related to the activities. Therefore, the workers need constant interaction with people, such as medicine, nursing, teaching, among others. Thus, when the worker cannot maintain personal balance, he may develop the professional wearing disease, that is, the Burnout Syndrome (BS) $[1,2]$.

Thus, the development of the BS is related to a gradual process of mood and demotivation wearing with physical and psychological symptoms. The worker loses the sense of his relationship to work, making things no longer so important, that is, a labor absenteeism. In this sense, the definition of $\mathrm{BS}$ is the result of chronic interpersonal stressors interactions at work and characterized by emotional wearing, depersonalization (or cynicism) and reduction of personal accomplishment (or professional effectiveness) [2].

On this subject, emotional exhaustion (EE) is presented by severe fatigue, lack of strength to face the day's work and the feeling of being required beyond its limits. Depersonalization (DE) is distinguished by emotional detachment and indifference to work and all who are part of its working cycle, especially with patients. Finally, the reduction of personal accomplishment (PA) is expressed at the lack of prospects for the future, frustration and feelings of incompetence and failure. Moreover, professionals are affected by symptoms of insomnia, anxiety, difficulty concentrating, changes in appetite, irritability, and depression [2, 3].

In this perspective, Nursing is classified as the fourth most stressful profession in the public sector because their activities are directly related to pain, disease, and death. In Brazil, it is revealed that most nurses are concentrated in public or private hospitals, dealing daily with these processes and administrative pressures. Thus, the healthcare professional lives in constant anxiety, sense of loss and fragility of patients daily with these processes [3].
Thus, the nursing staff, by its very nature and characteristics of its work is susceptible to occupational stress phenomenon due to the responsibility for the life and the proximity to the clients for whom the suffering is almost inevitable $[4,5]$. The reason for the development of the study is on the importance of knowing the stressors that lead to the development of BS in nursing professionals to optimize measures to prevent disease and promote a better quality of life to these professionals. Given this context, the following question emerged: What are the risk factors for the onset of BS?

Therefore, the study aimed to identify the factors that contribute to the development of BS in nursing professionals. Thus, the relevance of the study is to contribute to the advancement of scientific means on the relationship established between the stressful work factors with the development of labor syndromes.

\section{Method}

The integrative review method was used, since it gathers and summarizes results of research on a limited topic in a systematic and organized way, contributing to the deepening of knowledge of the topic investigated and offering support for a professional practice based on scientific knowledge.

For this study, the six stages of the development of the integrative review process were followed: elaboration of a guiding question, establishing the objectives of the review and inclusion and exclusion criteria of the articles; definition of the information to be taken from the research; selection of articles in the literature; analyzing the results; discussion of findings and presentation of the review [6].

The following question was formulated to conduct this review: What are the most incidents risk factors for the onset of the burnout syndrome in nursing professionals?

Original articles answering both or one of the guiding questions were included. Articles in editorial format, letter to the editor or opinion of experts, 
articles unavailable in full and not freely available on the selected databases were excluded.

The search for articles was held in September 2014 in the databases of the Virtual Health Library (BVS): Latin American and Caribbean Center on Health Sciences (LILACS), Bank of Nursing data (BDENF) and electronic library Scientific Electronic Library Online (SciELO). Uncontrolled descriptors were used, found in the Health Sciences Descriptors (DeCS) and Medical Subject Headings (MeSH): "Professional Burnout" "Occupational Diseases," combined through the Boolean operator "AND" with the descriptor "Nursing."

After the procedure of electronic search in the mentioned databases, there was an evaluation of articles by four reviewers, and later the results were compared to ensure that the articles met the inclusion criteria. Articles were evaluated as relevant and methodologically appropriate to maintain quality research studies, using a form for evaluation studies prepared by the Critical Appraisal Skills Program (CASP) [7]. Those who have achieved a minimum score of seven or maximum ten points were included in the sample.

Thus, the publications were initially pre-selected, based on reading the title and abstract. Then, they were read in full, and the final sample of this integrative review was identified.

In this step, a total of 233 articles were found $($ Scielo $=38$, LILACS $=143$ and BDENF $=52$. Thir- teen of them were included in the final study sample. Thus, all research steps can be seen in Figure 1.

Figure 1: Results of the search for articles in selected electronic databases. Natal/RN, Brazil. 2014.

Crossing result: "Professional Burnout" and "Occupational Diseases" and "Nursing"

Articles Found $=233$

\begin{tabular}{c|c|c|c|}
\hline SCIELO & LILACS & BDENF & $\begin{array}{c}\text { Selected by } \\
\text { Reading the } \\
\text { title and the } \\
\text { abstract }\end{array}$ \\
\hline 38 & 143 & 52 &
\end{tabular}

Selected for a full reading 36

13

Selected for

Literature Review

\section{Results}

For a better understanding, the results were categorized. The information provided by the 13 studies were listed, addressing some stressor in nursing labor activity. The characterization of the articles regarding the origin, authorship, title, stressors, the type of research and scientific evidence level are described in Table 1.

In this perspective, regarding the year of publication of the studies, 2013 (3.23\%), 2012 (3.23\%)

Table 1. Characterization of articles according to the origin, authorship, title, objective, type of research and level of scientific evidence. Natal/RN, Brazil, in 2014.

\begin{tabular}{|c|c|c|c|c|c|c|}
\hline Database & $\begin{array}{c}\text { Year of } \\
\text { Publication }\end{array}$ & Authorship & Title & Stressors factors & $\begin{array}{l}\text { Type of } \\
\text { study }\end{array}$ & $\begin{array}{l}\text { Level of } \\
\text { Evidence }\end{array}$ \\
\hline Scielo & 2013 & Monte PF, et al. & $\begin{array}{l}\text { The stress of } \\
\text { professional } \\
\text { nurses } \\
\text { working in the } \\
\text { intensive care } \\
\text { unit. }\end{array}$ & $\begin{array}{l}\text { The constant presence of death } \\
\text { and emergency situations; lack of } \\
\text { staff and material; constant noise } \\
\text { of the equipment; unpreparedness } \\
\text { for the changes of technological } \\
\text { arsenal; the suffering of family } \\
\text { members; the degree of } \\
\text { responsibility in decision-making; } \\
\text { conflict in the relationship among } \\
\text { professionals. }\end{array}$ & $\begin{array}{l}\text { Cross-sectional } \\
\text { study }\end{array}$ & 4 \\
\hline
\end{tabular}




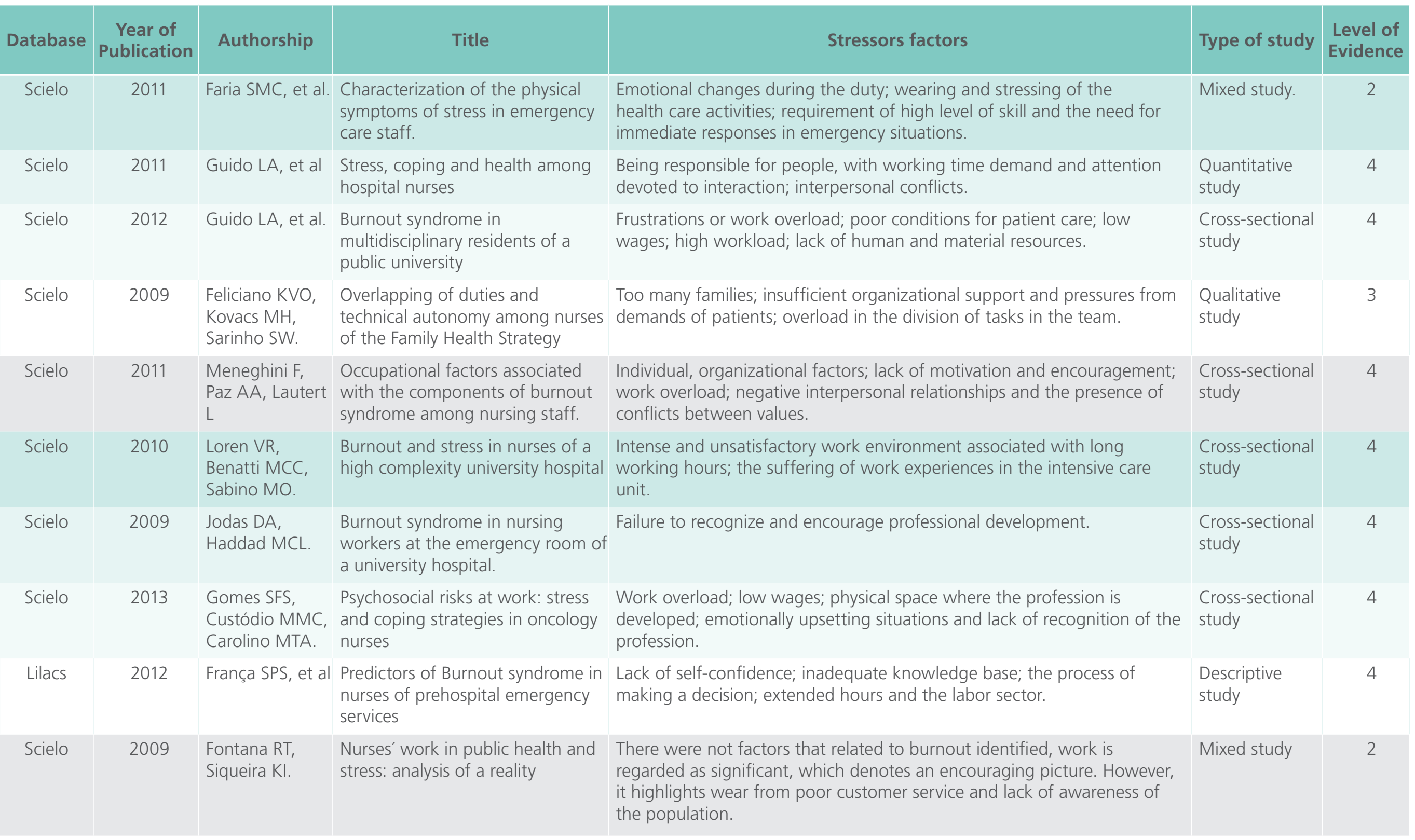




\begin{tabular}{|c|c|c|c|c|c|c|}
\hline Database & $\begin{array}{c}\text { Year of } \\
\text { Publication }\end{array}$ & Authorship & Title & Stressors factors & Type of study & $\begin{array}{l}\text { Level of } \\
\text { Evidence }\end{array}$ \\
\hline Scielo & 2012 & $\begin{array}{l}\text { Versa GLGS, } \\
\text { et al. }\end{array}$ & $\begin{array}{l}\text { Occupational } \\
\text { stress: } \\
\text { evaluation of } \\
\text { critical care } \\
\text { nurses working } \\
\text { at night }\end{array}$ & $\begin{array}{l}\text { Working conditions (night } \\
\text { work, critical sector and closed), } \\
\text { patient severity and management } \\
\text { activities associated with direct } \\
\text { assistance. }\end{array}$ & $\begin{array}{l}\text { Cross-sectional } \\
\text { study }\end{array}$ & 4 \\
\hline Scielo & 2013 & $\begin{array}{l}\text { Schimidt DRC, } \\
\text { et al. }\end{array}$ & $\begin{array}{l}\text { Quality of life } \\
\text { at work and } \\
\text { burnout in } \\
\text { nursing workers } \\
\text { at the Intensive } \\
\text { Care Unit }\end{array}$ & $\begin{array}{l}\text { Job dissatisfaction; duration of } \\
\text { working hours; the complexity of } \\
\text { human and labor relationships; } \\
\text { professional autonomy; very } \\
\text { demanding about the skills and } \\
\text { abilities and proper planning of } \\
\text { human and material resources. }\end{array}$ & $\begin{array}{l}\text { Descriptive } \\
\text { study }\end{array}$ & 4 \\
\hline
\end{tabular}

and 2011 (3.23\%) had the same quantity of publications. The other years, as in 2009 (03) 2010 (01), composed the rest of the selection. In this context, publications were distributed in different journals: Revista Acta Paulista (03), Revista Latino-Americana de Enfermagem (02) Revista Escola de Enfermagem USP (03), Revista Cogittare Enfermagem (01) Revista Gaúcha de Enfermagem (01), Revista de Saúde Pública (01), Revista Brasileira de Enfermagem(01) e Revista de Enfermagem Texto e Contexto (01).

About the BS, the stressors are intensified in daily care actions. Thus, the selected studies address several factors, which include: professional dissatisfaction, poor working conditions, interpersonal relationships, lack of resources materials, extensive working hours and low wages. It is noteworthy that many of these conditions reflect the great responsibility of the professional nurse in various sectors of activity, but it is a determining factor in the professional quality of life, especially in leaving him susceptible to developmental disorders.

\section{Discussion}

The stress situation is generated by the perception of stimuli that cause emotional and disturbance exhaustion. It is an adaptive process, characterized by physiological and psychological disorders. In the workplace, stress is together with the phenomena present in the body, and it can affect the worker's health, giving different responses among individuals, leading to personal friction $[9,10]$.

The nursing staff, by its very nature and characteristics of its work, shows to be susceptible to occupational stress phenomenon due to the responsibility for the life and the proximity to the clients for whom the suffering is almost inevitable. A study conducted in a large hospital showed the intensive care unit and emergency care sector as the most stressful working places, not absolving the other sectors to emerge stressful conditions [11].

In this sense, in a research developed at the University hospital to detect psychosomatic repercussion in nursing workers, most of them had headaches caused by tension or muscle pain and then a sense of fatigue, being the cause for upwelling of these symptoms is the excessive workload due to poor remuneration and poor working conditions $[11,12]$.

Contrasting the findings of the above research, a study developed with 28 nursing professionals in basic health units in the state of Maranhão showed that the casuistic factors for this negative impact outcropping behavioral disorders are the instability of social relationships, family or interpersonal, or in situations leading frustration [13]. 
Moreover, due to this situation, the nursing professional is susceptible to the development of the BS, characterized as a chronic labor response involving negative attitudes and behavioral changes related to the work context to disregard the human side. The concept of Burnout diverges directly from stress conditioning that is facing reactions of the organism to aggressions of various origins, able to disturb the internal balance of the human being [14].

Thus, when the stressors are not stopped, through ways of improving both the nursing professional and management, in the private sector, or public sector, the BS becomes a chronic disease causing a change in people's lives, not only in the structure and functioning of the body, but in quality of life, the development of new habits, review of the roles and members of the syndrome of development as a process of living. Thus, the nurse is vulnerable to develop personality disorders which directly affects their psyche [15] - [16].

In some centers that study the BS at the University of São Paulo (USP), it is shown that the output for this work pauperization to nursing workers is encouraging their activities through wage improvements, lower hourly workload, tasks distributed equally and favorable conditions because from these precepts, the managers of public and private institutions produces quality [17]. However, this scenario is still an achievement to be pursued by the working class, as many managers do not care about the health of their workers, just aiming to production and profit. [18]

However, simple actions can mitigate this stressor environment of nursing professionals in the workplace, as elucidations on ergonomics, the practice of gymnastics to reduce the possibility of work-related illnesses, software that optimizes the practical assistance, practical invasive devices and fast and switching professionals across the sectors. From this action and especially the participation of workers, the missing days of these professionals tend to de- crease and assistance be holistic and not technicalities grounded in the pharmacological treatment model [19].

Thus, through a continuing or permanent education, health promotion practices are mechanisms to improve the quality of life of professionals. In this respect, it is believed that education, along with the nursing professionals have an essential role in controlling stressor factors and developments syndromes since their complications are closely linked to knowledge of proper daily personal care and style healthy life [20].

Educational activities contribute to a better quality of life. However, some issues should be considered to achieve effective results, as the phase of the life cycle and its peculiarities, given that awareness and education are key factors for proper control and prevention. Currently, there is an increase in life expectancy, as a higher incidence of chronic noncommunicable diseases. Therefore, it is considered crucial that health professionals target their professional practice to actions that lead to independence, autonomy and quality of life [21].

\section{Conclusion}

When analyzing the studies that the main stressors of nursing professionals are in the excessive workload, low wages, and poor working conditions were found, in addition to the emotional instability due to a negative experience in the social sphere, such as family and sentimental disappointments.

Therefore, it can be inferred that changes and improvements in the workplace should be developed by managers. Prevention and promotion of functional labor quality are one of these actions important in health education practices.

It is suggested then, actions incorporated into the daily work, exemplified with the preparation of informative booklets that discuss this syndrome, creating conversations rounds where professionals can share their needs are effective strategies that 
can guide the nursing professional as the involvement of stressors and mitigate the effects of the syndrome.

In this context, it was necessary to create laboratory programs for health professionals, especially nurses, as they remain much of their journey in relation to families, patients and other professionals.

\section{References}

1. Farias SMC, Teixeira OLC, Moreira W, Oliveira MAF and Pereira MO. Caracterização dos Sintomas físicos de estresse na equipe de pronto atendimento. 2014. Rev Esc Enferm USP, 45. 722-9.

2. Bezerra FN, Silva TM and Ramos VP. Estresse ocupacional dos enfermeiros de urgência e emergência: Revisão Integrativa da Literatura. 2012. Acta Paul Enferm, 25. 151-6.

3. Monte PF, Teixeira Lima FE, Neves FMO, Studart RMB and Dantas RT. Estresse dos profissionais enfermeiros que atuam na unidade de terapia intensiva. 2013. Acta Paul Enferm; 26. 421-7.

4. França SPS, Martino MMF, Aniceto EVS and Silva LL. Preditores da Síndrome de Burnout em enfermeiros de serviços de urgência pré-hospitalar. 2012. Acta Paul Enferm, 25.68-73.

5. Fernandes MA, Sousa FK, Santos JS, Rodrigues JÁ and Marziale MHP. Síndrome de Burnout em profissionais de enfermagem do serviço de atendimento móvel de urgência. 2012. Cuid fundam online 4:3125-35

6. Polit DF, Beck CT and Hungler BP. Fundamentos de pesquisa em enfermagem: métodos, avaliação e utilização. 5. ed. Porto Alegre: Artmed; 2004

7. Trust MKP. Critical Appraisal Skills Programme (CASP): making sense of evidence. London (UK): Oxford; 2002.

8. Cunha AP, Souza EM and Mello R. Os fatores intrínsecos ao ambiente de trabalho como contribuintes da síndrome de Burnout em profissionais de enfermagem. 2012. Cuid fundam. 29.

9. Rossi SS, Santos PG, Passos JP. A síndrome de Burnout no enfermeiro: um estudo comparativo entre atenção básica e setores fechados hospitalares. 2010. Cuid fundam online, 2:1232-39

10. Schmoeller R, Trindade LL, Neis MB, Gelbcke FL and Pires DEP. Cargas de trabalho e condições de trabalho da enfermagem: revisão integrativa. Rev Gaúcha Enferm 2011, 32. 368-77.

11. Versa GLGS, Murassaki ACY, Inoue KC, Augusto de Melo W, Faller JW and Matsuda LM. Estresse ocupacional: avaliação de enfermeiros intensivistas que atuam no período noturno. 2012. Rev Gaúcha Enferm, 33. 78-85

12. Teixeira RC and Mantovani MF. Enfermeiros com doença crônica: as relações com o adoecimento, a prevenção e o processo de trabalho. 2009. Rev Esc Enferm USP;43. 415-21.
13. Schmidt DRC, Pladini $M$, Biato C, Pais JD and Oliveira AR. Qualidade de vida no trabalho e burnout em trabalhadores de enfermagem de Unidade de Terapia Intensiva. 2013. Rev Bras Enferm 66(1).13-7.

14. Lima MB, Silva LMS, Almeida FCM, Torres RAM and Dourado HHM. Agentes estressores em trabalhadores de enfermagem com dupla ou mais jornada de trabalho. 2013. Cuid fundam online;5(1):3259-66.

15. Guido LA, Linch GFC, Pitthan LO, Umann J. Estresse, copinge estado de saúde entre enfermeiros hospitalares. Rev Esc Enferm USP .2011 45(6):1434-9.

16. Guido LA, Silva RM, Goulart CT, Bolzan MEO, Lopes LFD. Síndrome de Burnout em residentes multiprofissionais de uma universidade pública. Rev Esc Enferm USP 2012;46(6):1477-83.

17. Lorenz VG, Benatti MCC, Sabino MO. Burnout e estresse em enfermeiros de um hospital universitário de alta complexidade. Rev Latino-Am Enfermagem. 2010;18(6).

18. Meneghini F, Paz AA, Lautert L. Fatores ocupacionais associados aos componentes da síndrome de Burnout em trabalhadores de enfermagem. Texto Contexto Enferm. 2011; 20(2): 225-33.

19. Theme Filha MM, Costa MAS, Guilam MCR. Estresse ocupacional e autoavaliação de saúde entre profissionais de enfermagem. Rev Latino-Am Enfermagem. 2013;21(2)

20. Fontana RT, Siqueira KI. O trabalho do enfermeiro em saúde coletiva e o estresse: análise de uma realidade. Cogitare Enferm. 2009; 14(3):491-8.

21. Jodas DA, Haddad MCL. Síndrome de Burnout em trabalhadores de enfermagem de um pronto socorro de hospital universitário. Acta Paul Enferm.2009;22(2):192-7.

\section{Publish in International Archives of Medicine}

International Archives of Medicine is an open access journal publishing articles encompassing all aspects of medical science and clinical practice. IAM is considered a megajournal with independent sections on all areas of medicine. IAM is a really international journal with authors and board members from all around the world. The journal is widely indexed and classified Q2 in category Medicine. 